8 per cent of the papers are in Russian, and for those whose linguistic attainments do not include this language neither summaries nor even title are included in any other.

The book is divided into three sections dealing broadly with the biological, modical and sociological aspects of ageing. It would, I think, be invidious to comment individually on selected papers, and the general impression given by the three separate sections may be of more help to would-be readers.

Although the biological section ranges from botany to palaeo-pathology, the main accent is on vascular changes, where the involvement of proteins, polysaccharides, lipids and hormonal secrotions is considered.

The geriatric section is, as might be expected, much more varied in its approach, ranging from general questions of the care of the aged to specific topics and specific conditions which require particular control in aged subjects. For British geriatricians it is unfortunate that this section contains the highest proportion of papers in Russian.

One or two of the papers in the sociological section present studies which are peculiar to Hungary or to ageing in a socialist republic, but the majority touch on problems which are of universal interest. In this section in particular, I, as a biochemical gerontologist, found the shortness of the papers most frustrating.

In general this is a mammoth publication which should serve as very good general roading for all those concerned in similar work. It is only to be deplored that three years have elapsed between the congress and its publication.

David A. Hatit

\section{THINKING BROKEN DOWN}

\section{The Pathology of Thinking}

By B. V. Zeigarnik. (The International Behavioral Sciences Series.) Translated from the Russian by Basil Haigh. Pp. xvi+211. (Now York : Consultants Bureau, 1965.) 12.50 dollars.

TO those who imagine contemporary Russian psychology to consist entirely of post-Pavlovian elaborations, experimental and theoretical, out of touch with the actual behaviour of individuals, this book may come as something of a surprise. Dr. Zeigarnik presents a great deal of empirical data from her investigations of the breakdown of normal intellectual processes in a variety of pathological conditions ranging from schizophrenia to arteriosclerosis, and sets them in a framework which seems to owe much to the inspiration of Vygotsky, who for a number of years exercised more effect in the West than in his native land.

In her introductory chapter, Dr. Zeigarnik accepts much from the classical German school of neuropsychiatry of the late nineteenth century, notably from Breuler, though she is perhaps rather unsympathotic and a trifle doctrinaire in stressing the dependence of its views on 'idealistic' and 'faculty' prosuppositions. Her account of more recent American, German and British contributions is sometimes so comprossed as to impose some distortion. But her basic point is clear. 'Classical' theories-whether they tend, on one hand, to doctrines of cerebral localization or of distinct, innate facultios, or, on the other, to cerebral mass-action or a Gestalt principle of function-are inadequate inasmuch as they neglect the essontial characteristic of thought, which is to issue in action. It is in this latter conviction that Zeigarnik approaches the pathology of intellectual processes.

Her methods of investigation are quite largely ones similar to those used by others during tho past forty years. Classification of objects, the perception of exceptions, understanding of proverbs, and the arrangement of pic- tured events in Jogical time sequence «re all test procedures of proved value and much used by clinical psychologists the world ovor. An interesting frosh element is, howevor, provided by the 'method of pictograms' (suggested by A. R. Luria) in which the patient is required to devise his own pictorial aids to memory for words, and the character of these aids provides data for an assessment of his abstractive capacities and tendencies.

So far as case-material is concerned, Zeigarnik has drawn her net wide. It comprises the major psychoses, traumata, vascular disease and perinatal injury and in fective conditions. It is a pity that relatively littlo attention is paid, in any adequate statistical way, to assessment, of the test results in terms of differences of pathology. But Dr. Zeigarnik's emphasis (in what is stated at the outset to be a students' text-book) is on the discernment of the main lines of intellectual breakdown regardless of its cause. Those lines are three: (1) of abstraction and generalization; (2) of the logical course; (3) of the purposiveness, of thinking. That these three categories emerge so closely similar to the conclusions of other workers whose basic assumptions may have differed considerably is indeed a hopeful sign. Dr. Zeigarnik makes a contribution of considerable valuo, less on grounds of originality than through the admirable and feiscinating way in which she illustrates her contentions by direct reference to her empirical material. Every now and then, however, her presentation seems to draw attention rather to the stereotyped character of normal behaviour adjudged 'correct' than to the true deviance of abnormal function.

It seems sad that academic Russian, at least in a field like this, apparently cannot go with any ease into simple, direct English. There is a cold didactic atmosphere about this translation which may perhaps be unavoidable, but which is notably at variance with many people's experience of conversational exchange with Russian colleagues. The book ought to be read, not only by those with direct concern with the breakdown of thought in pathological conditions but also by anyone interested in the analysis of the supposedly normal.

R. C. Olmfteli

\section{PHARMACY IN HISTORY}

\section{Pharmacy in History}

By Prof. G. E. Trease. Pp. vi + 265. (London: Baillière, Tindall and Cox, Ltd., 1964.) $50 s$.

$\mathrm{M}$ ODERN materia medica is so largely concerned with defined and standardized substances that its evolution from the vegetable, animal and mineral materia medica of earlier times tends often to be overlooked. The isolation of chemical constituents from natural products and the evaluation of their biological effects, leading to the synthesis and evaluation of analogues, are rolatively recent developments. It is fascinating, therefore, to recall our inheritance from earlier times and the periods of progress, stagnation and docline in medicine, science and the arts that have occurred. The history of medicine and pharmacy is not one continuous progress. It is important, to be rerninded of this lest we become too obsessod with the seeming miracles of modorn therapy. There are many "diseases of medical progress" and many problems to be solved in the safe use of a vast and growing range of powerful therapeutic agents.

Man has learnt much by trial and orror through the ages, and will doubtless continue to do so, however much scientific devolopment encourages the planning of the trials. It is very interesting and instructive to read, in this coneise and excellent monograph by Prof. Trease, of the development of pharmacy in history.

Pharmacy is concerned with medicines, and there have been many seemingly strange aberrations in its historical 